\title{
Spatial-problem based learning (SPBL) development (preliminary studies for geography learning)
}

\author{
Waode Yunia Silviariza *, Budi Handoyo * \\ * Department of Geography Faculty of Social Sciences Universitas Negeri Malang, \\ Indonesia
}

\begin{tabular}{l}
\hline \hline ARTICLES INFO \\
\hline Profil Articles: \\
Sent: $19-10-2019$ \\
Approved: 6-12-2019 \\
Published: $30-1-2020$
\end{tabular}

Key words:

spatial based learning; problem based learning; development; SPBL

\section{Correspondent Author:}

Waode Yunia Silviariza

Department of Geography

Universitas Negeri Malang

Jl. Semarang No. 5 Malang, Indonesia

E-mail: waodeyunias.work@gmail.com
Problem Based Learning (PBL) is widely developed and applied to many multidisciplinary sciences. PBL in learning geography needs to be developed to fit the main characteristics of geography, namely the spatial approach. In geography learning, the Spatial Based Learning (SBL) model is often used. SBL is a model that encourages students to think in space. Integrating PBL and SBL will create learning models that are appropriate to the characteristics of geography. The purpose of this study is to develop PBL models by presenting phenomena or spatial problems. The research development design is the method of Borg and Gall (2006): (1) needs analysis, (2) planning, (3) developing initial product forms, (4) initial field testing, (5) major product revisions, (6) carrying out testing field, (7) product revision, and (8) final product revision. The research subjects were geography students and the validator was a doctor of geography education. Data from the validator in the form of in-depth interviews are used to improve product quality. Data from students in the form of questionnaire results are used to determine product eligibility. Data analysis was performed descriptively and statistically. The product of development is Spatial Problem Based Learning (SPBL) which has five steps, namely: (1) spatial problem orientation, (2) formulating spatial problems, (3) collecting and organizing spatial data, (4) analyzing spatial data and discussion, (5) communication. The results of expert validation have a score $>65 \%$. The average field test score of the five SPBL syntaxes is 93.2. Based on trials that the SPBL syntax is feasible

This is an open access article under the CC-BY-SA license

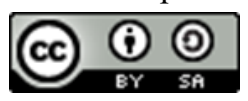

\section{INTRODUCTION}

Geography learning is entering the 21 st century. Geography learning now has the goal to prepare students' abilities to face future challenges. These capabilities include; creativity and innovation; creative thinking and problem solving; and communication and collaboration skills (Nagel, 2008). The goal of 21st-century geography learning will be achieved if students can be active so that the learning that has taken place becomes meaningful. 
Jurnal Pendidikan Geografi:

Kajian, Teori, dan Praktik dalam Bidang Pendidikan dan Ilmu Geografi

Volume 25, Nomor 1, Jan 2020, Hal 69-79

Several learning models support the creation of meaningful geography learning. One of the meaningful learning models is Problem Based Learning (PBL). PBL is a problem based scientific learning model. PBL concentrates on the activeness and collaboration of students to construct their knowledge. PBL is a learning model that encourages students to learn and be actively involved with problems so that the quality of learning is more meaningful (Yew \& Goh, 2016).

There are three main activities in PBL namely collaboration, independent learning, and constructive. Research shows that the three activities in the PBL cycle are $53.3 \%$ as collaborative activities; $27.2 \%$ of independent learning activities; and $15.7 \%$ are constructive (Yew, Schmidt, 2009). Other advantages of PBL are structuring knowledge, developing reasoning processes, developing independent learning skills and increasing student motivation for further learning (Barrows, 1986). Therefore, with PBL's advantages, the development of PBL learning models will further concentrate on meeting the needs of students in the 21 st century.

PBL has been recognized in education since the 19th century. 1920s PBL was used by Celestine Freinet (Jusuf, 2009). In 1966 PBL was developed by Jim Anderson, Howard Barrows, and John Evans from McMaster University, Canada (Scherpbier \& Hillen, 2010). The history of modern PBL begins again in the early 1970s at McMaster University Faculty of Health Science, Canada (Zubairi, et al., 2008). Then, PBL is applied globally in various professional schools (Burgess et al., 2016). PBL has been applied in architecture (Quilis, et al., 2017; Artieda, et al., 2018), business administration (Haengnam, 2017, chemical engineering (Gu et al. , 2016), engineering studies (Bravo et al., 2018), law school (Wijnen, et al., 2017; Sørensen, 2017; Claessens, 2019) in the health sector (Chang, 2016; Kwan, 2017; Sakyi \& Kuofi) and teacher education (Oberlander \& Talbert-Johnson, 2004).

Some reports state that PBL has been applied in various fields of science and higher education curriculum. PBL has been integrated in biological science (Szeberenyi, 2005), biochemistry (Osgood, et al., 2005), calculus (Mokhtar, et al., 2010), chemistry (Overton and Randles, 2015), economics (Chulkov \& Nizovtsev, 2015; Smith, \& Ravitz, 2008), geology (Soares, et al., 2015), psychology (Szulevicz \& Jensen, 2013). Also, many reports on the results of the implementation of PBL in the curriculum in schools. PBL can be used effectively in a variety of student populations, (Khoiriyah \& Husamah, 2018; Anjarwati, et al., 2018; Nariman \& Chrispeels, 2016; Surya \& Syahputra, 2017; Chao et al., 2016). However, PBL is not a learning model that can be easily adopted. Successful implementation of PBL can be achieved to the maximum if there is careful attention related to the preparation and design of a mature scenario (Hynek, 2017). Therefore, the development of PBL must be adjusted to the characteristics of a science.

Kilroy shares PBL steps in the health sector which consists of (Kilroy, 2003); (1) clarify the terms and decide the problems, (2) analyze the problems, (3) identify study priorities for the scenario (4) formulate learning objectives for the problems, (5) individual studies, (6) the group meet and share their findings, (7) identify areas for improvement. In addition to the health sector, PBL has been applied to the school curriculum. First, PBL steps according to Arends (2008) include; (1) problem orientation; (2) the organization of student assignments to research; (3) independent and group investigations; (4) develops, presents results and exhibits; (5) process analysis and evaluation. Second, the steps of the Problem Based Learning model according to Kosasih (2014) namely; (1) orienting students towards problems; (2) raises problems; (3) collecting data; (4) formulating answers; (5) communicating. 
Jurnal Pendidikan Geografi:

Kajian, Teori, dan Praktik dalam Bidang Pendidikan dan Ilmu Geografi

Volume 25, Nomor 1, Jan 2020, Hal 69-79

PBL is also often used in geography education. PBL in geography is widely applied even in various countries, but it has not been successful so it needs to be continuously developed (Pawson et al., 2006). The application of PBL in geography education has not been able to meet the characteristics of geography learning competencies. PBL is still general in nature and the problems studied in learning have not focused on spatial as a geographical style. Therefore, PBL for geography needs to be developed to suit the needs and the main characteristics of geography, namely spatial.

On the other hand, began to develop a spatial learning model called Spatial Based Learning (SBL). SBL developed since the 1980s by Hooper.

The development of SBL by Hooper began because at that time learning geography was considered to be less attractive and monotonous. Learning geography by only presenting maps, recognizing pictures and drawing maps is not enough to foster geography knowledge well (Hooper, 1981). Furthermore, Breuker also developed SBL into six steps. The SBL steps developed by Brueker include; (1) selection of key concepts; (2) writing key concepts; (3) make a list of attributes; (4) linking key concepts into spatial order; (5) rearranging spatial representation; and (6) comparing the spatial representation with text (Breuker, 1984).

Siler developed SBL into classroom floor models and papier-mache models (Siler, 1998). The next SBL figure is Geresmelh. Geresmelh produces three steps of spatial learning, namely (1) teaching location, circumstances, and relationships; (2) describe location conditions; and (3) explore linkages with other locations (Geresmelh, 2008). In 2017 SBL was again developed by Handoyo and Purwanto. There are seven steps of SBL by Handoyo and Purwanto, including (Handoyo, 2017); (1) delivery of objectives, (2) observation, (3) communication and confirmation, (4) elaboration and integration, (5) discussion, (6) conclusions, and (7) reflection and follow-up.

SBL is a learning model that can encourage students to think spatially. Spatial thinking involves visualization and interpretation of location, position, distance, direction, patterns, relationships, movements, and changes through time and space (Sinton et al., 2014). Thus, SBL is a geography learning model that can encourage students to understand the physical features of the earth, including understanding the reciprocal relationship between earth and humans and vice versa.

The development of learning models is carried out to create effective learning. However, SBL is not necessarily effective for 21 st-century geography learning. This is seen from the SBL syntax which is less focused on exploring creativity activities; creative thinking; and problem-solving students. Very few students describe spatial thinking when solving problems (Hespanha, 2009). Thus, it needs to be developed to fit the learning of 21st-century geography.

PBL and SBL learning models have their respective advantages. PBL excellence is that students construct knowledge from the problem being studied; students think critically to solve a problem; students work together in teams. PBL can develop students cognitively, affective, and psychomotor. Also, there are opportunities for students to learn in their learning styles. While the superiority of SBL can create learning that gives students understanding, understanding, and knowledge of space, location, phenomena, and links between spaces.

These advantages show that PBL has advantages in developing problem-solving abilities. While SBL has the advantage in presenting phenomena spatially. Therefore, if the advantages of the two models are integrated, we will get a syntax of learning models that are more in line with the characteristics of 21 st-century geography learning that 
Jurnal Pendidikan Geografi:

Kajian, Teori, dan Praktik dalam Bidang Pendidikan dan Ilmu Geografi

Volume 25, Nomor 1, Jan 2020, Hal 69-79

presents phenomena or problems spatially with creativity and innovation; creative thinking and problem-solving; communication and collaboration skills.

\section{METHODS}

This research is a research development to produce a new learning model by integrating the two existing models. The two models are Problem Based Learning (PBL) and Spatial Based Learning (SBL). For product development using an 8-step design modification with the following explanation.

Research and information collecting. Activities at this stage are needs analysis with literature studies and observations. Literature and curriculum studies obtained results in the form of implementation of the educational institution's learning system. While observation in the field aims to find out the process of learning geography at Universitas Negeri Malang directly.

Planning. Research activities at this stage are the development of learning models including determining research and development goals, defining variables, formulating product designs and determining work procedures and due diligence. The work of this stage is the prototype design of learning models that are ready to be validated by experts.

Develop the preliminary form of a product. Preparation of the design of learning models based on literature studies, previous research, model development theory and the feasibility of its implementation. The principle of developing a learning model is related to the characteristics of the learning model that has a scientific step, a specification of planned learning outcomes, specifications for the scope of learning, performance criteria, ways of implementing them. The characteristics of the field of geography are based on a spatial perspective.

Preliminary field testing. The validator assesses the feasibility of the prototype of the learning model that has been formulated (the feasibility of the concept and use of theory).

Main product revision. The initial revision was made after receiving criticism of suggestions and input from the validator.

Main field testing. Limited trials were conducted on geography education students. The aim is to find out and test the feasibility of the syntax of the learning model developed.

Operation product revision. Revisions are made after getting the results of the due diligence. Learning models will be adjusted and refined.

Final product revision. The finalization of the learning model is the final revision stage which is based on input and results of the trial. The following will be presented with a description of the results of the development of the SPBL model. Five SPBL model syntaxes have been formulated. The syntax of the SPBL geography learning model is as follows; (1) spatial problem orientation, (2) formulating spatial problems, (3) collecting, organizing spatial data and information, (4) analyzing and discussing spatial data, (5) communication.

Data collected by interviews and questionnaires. An in-depth interview and questionnaires with the validator was conducted to obtain comprehensive information about the SPBL. The expert validator is a lecturer in geography education from the geography department of Universitas Negeri Malang with teaching experience for more than five years.

The trial was conducted on 30 students majoring in geography education in the fifth semester. The selection of the subject is because fifth-semester students are considered as users of the learning model. Another reason is that the student has been able to 
assess because he has gained a variety of learning experiences using methods, models, and learning strategies in learning and teaching students. The research was conducted in the Department of Geography Education, Faculty of Social Sciences (FIS), Universitas Negeri Malang (UM). The trial results were analyzed descriptively with a percentage.

There are five questions in the questionnaire submitted to students as research subjects. The five questions are: (1) Can student learning activities in problem orientation recognize the problems that occur spatially ?; (2) Can student learning activities in problem formulation ensure that problems will be spatially formulated ?; (3) Can student learning activities in data collection and organization ensure that data will be collected and spatially organized ?; (4) Does the student's activity in analyzing data and discussing it ensures that the data will be analyzed and discussed spatially?; (5) Are the students' activities in communicating the results of the discussion in ensuring the results will be effectively communicated?

The answer from the research subject/student to the question is "Yes" or "Less" or "No". Answer "Yes", get a score of 3. Answer "Less" gets a score of 2. Answer "No" gets a score of 1 . Then the score is processed with the following formula.

$$
\text { Score }=\frac{\text { Total Score }}{\text { Mns:Srore }} \times 100 \%
$$

The calculation results are tested with criteria $\geq 76$. If the results are the same or more 76, then the SPBL steps are valid or feasible. If less than 76 is declared invalid or not feasible. Likewise for the average score, when the average score from the calculation result is $\geq 76$, declared valid or feasible, so it can be used as a geography learning model. Conversely, when the average score is less than 76, the steps are declared invalid or inappropriate as a model of geography learning.

\section{RESULTS AND DISCUSSIONS}

The results of this research development are learning models called SpatialProblem Based Learning (SPBL). There are five SPBL syntaxes as a guide in implementing learning. The results of the validation are presented in table 1.

Based on the validator's opinion, the five steps of the SPBL can be applied in the geography class. As the implication, the learning process of geography becomes more scientific and spatial in solving a problem. Thus, creative, innovative, solving a problem,

Table 1. SPBL Validation Results by Validator

\begin{tabular}{lll}
\hline No & Items that are evaluated frequently & Regard \\
\hline 1 & Spatial Problem Orientation & can be applied \\
2 & Formulating Spatial Problems & can be applied \\
3 & Collecting \& Organizing Spatial Data/Information & can be applied \\
4 & Analyzing Data \& Discussion of Spatial Problems & can be applied \\
5 & Communication & can be applied \\
\hline
\end{tabular}


Jurnal Pendidikan Geografi:

Kajian, Teori, dan Praktik dalam Bidang Pendidikan dan Ilmu Geografi

Volume 25, Nomor 1, Jan 2020, Hal 69-79

Table 2. SPBL Field Test Results

\begin{tabular}{llcccccc}
\hline \multirow{2}{*}{ No } & \multirow{2}{*}{ Items that are evaluated frequently } & \multicolumn{3}{c}{ Sering } & \multirow{2}{*}{ Score } & Regard \\
\cline { 3 - 6 } & & 1 & 2 & 3 & & \\
\hline 1 & Spatial Problem Orientation & 0 & 2 & 28 & 98 & Valid \\
2 & Formulating Spatial Problems & 0 & 0 & 30 & 100 & Valid \\
3 & Collecting \& Organizing Spatial Data/Information & 1 & 6 & 23 & 82 & Valid \\
4 & Analyzing Data \& Discussion of Spatial Problems & 0 & 4 & 26 & 86 & Valid \\
5 & Communication & 0 & 0 & 30 & 100 & Valid \\
\hline
\end{tabular}

communicative and collaborative thinking processes in learning geography can be achieved.

The first syntax is orienting students to spatial problems. Students review a spatial phenomenon carefully. Spatial reviews are carried out directly in the field. The teacher facilitates students to recognize spaces with absolute and relative locations, recognize the characteristics of space and recognize factors related to the spatial. With these activities, students are trained to think spatially.

The second syntax is formulating a spatial problem. Students formulate questions from problems that have been identified in the previous syntax. This stage can be called the questioning stage. Questioning is the initial stage for students to think critically about a problem. At this stage, students are trained to look at problems spatially and formulate them.

The third syntax is collecting and organizing spatial data and information. At this stage, students collect and organize spatial data in the form of tables, graphs or diagrams. Students use the "Student Activity Sheet" that the teacher has designed to collect and organize spatial data. Thus, the process of collecting and organizing spatial data and information is easy to read and analyze.

The fourth syntax is analyzing spatial data. Students analyze the data that has been processed and discuss the data internally as a group. The analysis was carried out spatially with various analytical techniques following the characteristics of the data and its purpose. Data analysis can use data processing applications such as Geographic Information Systems (GIS), SPSS or others as needed.

The fifth syntax is communication. Students communicate their findings to others verbally or in writing in the form of diagrams, charts, pictures, and the like with the help of simple technological devices and or information and communication technology. Students present conclusions then discuss with other groups to get a different view of a problem. This activity trains students to be confident and develop scientific speaking skills in public (Lestari, 2017). The following will present the field test results to SPBL users in the following table 2.

Based on the five SPBL syntaxes, the highest score is 100, and the lowest score is 82. The highest score is the step Formulating Spatial and Communication Problems. The Spatial Problem Orientation Step gets a score of 92. Analyzing and Discussing Spatial Data has a score of 86. While in the Step for Collecting and Organizing Spatial Data / Information a score of 82 . The field test results show that the SPBL syntax has a score higher than the criterion (76). Thus the SPBL is expressed as a learning model that can be used in current geography learning.

Table 2 shows the functions of each SPBL syntax. The first syntax is Spatial Problem Orientation which shows a score of 98. This shows that the SPBL can create 
Jurnal Pendidikan Geografi:

Kajian, Teori, dan Praktik dalam Bidang Pendidikan dan Ilmu Geografi

Volume 25, Nomor 1, Jan 2020, Hal 69-79

problem-oriented learning activities and students can recognize problems that occur spatially. This activity is the result of curriculum analysis and student needs.

The second syntax is Formulating Spatial Problems. This syntax shows a score of 100. The score illustrates that student learning activities in the formulation of problems can ensure the problem will be spatially formulated.

The third syntax is Collecting and Organizing Spatial Data / Information. In this syntax, the score shows 82 . The score illustrates that student learning activities in collecting and organizing data can ensure that data will be collected and arranged spatially.

The fourth syntax is Analyzing and Discussing Data. This syntax gets a score of 86. The score shows that students' activities in analyzing data and discussing it can ensure the data will be analyzed and discussed spatially.

The fifth step is to show communication. This syntax gets a perfect score of 100 . The score illustrates that students' activities in communicating the results of the discussion in ensuring the results are effectively communicated.

\section{Discussion}

The result of this development is the SPBL learning model. SPBL syntax is the integration of SBL and PBL. The results of the integration obtained five steps or syntax of SPBL learning including spatial problem orientation, formulating spatial problems, collecting and organizing spatial data and information, analyzing spatial data and discussion (discussion) of results, and communication.

SPBL is useful for creating a unique and dynamic atmosphere of learning geography and can hone students' high-level thinking skills. SPBL is a form of completion in the field of geography of SBL and PBL which has excellent advantages. PBL excellence makes students able to solve problems with scientific thinking. The advantage of SBL is that it provides the ability to understand space. The advantages of both models are very good for honing thinking skills in the 21 st-century geography including creativity and innovation; creative thinking and problem solving; communication and collaboration skills. Also, the two models are closely related and provide benefits to each other. Therefore, the two models can be combined to provide new advantages in learning geography that is not in the superiority of both models. creative, innovative, solutive, communicative and collaborative.

These new advantages allow students to: (1) work in teams (collaborative and communicative) (2) identify and formulate problems spatially through scientific (creative) observation processes (3) critical thinking of a contextual (innovative) spatial problem ( 4) describe the relationship between one phenomenon with another (innovative) spatial phenomenon (5) the decision for a spatial problem with a scientific (creative) step. Thus, the distinct advantages of each learning model will be optimized by integrating the two models in geography learning to foster creativity and innovation; creative thinking and problem solving; student communication and collaboration skills to support the development of 21 st-century skills.

Also, the advantage of SPBL is developing the ability to think spatially. Spatial thinking is an abstract concept consisting of spatial perception, spatial orientation (Tambunan, 2006) spatial location, spatial visualization (Velez, 2006) including spatial relationships (Lohman, 1993). Spatial ability is related to one's ability to understand well the relationship between objects and space (Masykur, 2007).

SPBL is arranged based on the spatial thinking paradigm for the 21 st century. The presentation of information is followed by an ongoing problem, the orientation of the scientific spatial problem of an issue. Thus the learning material can foster creativity 
Jurnal Pendidikan Geografi:

Kajian, Teori, dan Praktik dalam Bidang Pendidikan dan Ilmu Geografi

Volume 25, Nomor 1, Jan 2020, Hal 69-79

and innovation; creative thinking and problem-solving; and students' spatial communication and collaboration skills so they can improve their geography skills.

Geography expertise includes the ability to compose geographic questions, collect spatial data, link data, analyze data, and communicate information (National Endowment for the Humanities 1912). Geography expertise is the aim of geography education. In the SPBL syntax or steps, there are problem orientation activities in space, spatial data collection, spatial data organization, spatial data analysis, and communication that can improve students' geography skills. Thus, the spatial thinking process can be critically carried out with SPBL.

\section{CONCLUSION}

The SPBL geography learning model has been developed. In the implementation, five steps are applied in the learning process. The syntax of the SPBL geography learning model includes; (1) spatial problem orientation activities, (2) formulating spatial problems, (3) collecting and organizing spatial data and information, (4) analyzing spatial data, (5) communication. The five steps of having an average score are higher than the criterion score (76). Thus the Five steps in the SPBL are suitable for use in geography learning. As an implication, if the SPBL is implemented there will be changed in the geography learning process. The geography learning process becomes more scientific, critical and spatial in solving a problem. Also, there is an association with the spatial, natural environment, and human life so that it can foster spatial thinking; creativity and innovation; creative thinking and problem solving; and communication and collaboration skills in growing geography skills.

\section{REFERENCES}

Anjarwati, P. G. P., Sajidan dan Prayitn, B. A. (2018). Problem-Based Learning Module of Environmental Changes to Enhance Students' Creative Thinking Skill. Biosaintifika: Journal of Biology \& Biology Education, 10(2), 313-319.

Arends, R. I. (2012). Learning to Teach ninth edition. New York : McGraw-Hill.

Artieda, C., Torres, T. L., \& Muniesa, A. V. (2018). PBL. Problem-Based Learning Cross-Application to the First Year Graphical Courses of the Degree in Architecture Architectural Draughtsmanship. Springer International Publishing AG 2018 E. Castaño Perea and E. Echeverría Valiente (eds.). https://doi.org/10.1007/978-3-31958856-8 21 assessment of its Purposes, Benefits and Risks. Journal of Geography in Higher Education. Vol 30 No 1. DOI: 10.1080/03098260500499709.

Barrows, H. S. (1986). A Taxonomy of Problem - Based Learning Methods. Medical Education. Vol 20. Issue 6. Pages 481-486 https://doi.org/10.1111/j.13652923.1986.tb01386.x

Bravo, L. E. C., Bermudez, G. M. T., \& Molano, J. I. R. (2018). Design and Application of a Creative Strategy Based on the Method of Problem-Based Learning (PBL) in Engineering Students. Learning Technology for Education Challenges. 168-180. DOI:10.1007/978-3-319-95522-3_15

Breuker, J. A. (1984). Spatial based learning strategy: chapter 2. A Theoretical Framework for Spatial Based Learning Strategies pages 21-46, https:// doi.org/10.1016/B978-0-12-352620-5.50008-4.

Burgess, A., Ayton, T., \& Mellis, C. (2016). Implementation of team-based learning in year 1 of a PBL based medical program: a pilot study. BMC Medical Education. DOI 10.1186/s12909-016-0550-3

Chang, B. J. (2016). Problem-based learning in medical school: A student's perspective. 
Jurnal Pendidikan Geografi:

Kajian, Teori, dan Praktik dalam Bidang Pendidikan dan Ilmu Geografi

Volume 25, Nomor 1, Jan 2020, Hal 69-79

Annals of Medicine and Surgery. http://dx.doi.org/10.1016/j.amsu.2016.11.011

Chao, J. Y., Tzeng, P. W., \& Po, H. Y. (2017). The Study of Problem Solving Process of E-book PBL Course of Atayal Senior High School Students in Taiwan. EURASIA Journal of Mathematics Science and Technology Education. ISSN 1305-8223 (online) 1305- 8215 (print) 13(3):1001-1012 DOI 10.12973/eurasia.2017.00654a

Chulkov, D., \& Nizovtsev, D. (2015). Problem-Based Learning In Managerial Economics With An Integrated Case Study. Journal of Economics and Economic Education Research Vol 16 No 1.

Claessens, S. J. F. J. (2019). The role of student evaluations in a PBL centered law curriculum: towards a more holistic assessment of teaching quality. The Law Teacher. https://doi.org/10.1080/03069400.2019.1580009

Gall, M. D., Gall, J. P., \& Borg, W. R. (2007). Educational research: An introduction (8th ed.). Boston: Allyn and Bacon.

Gersmehl, P. (2008). Teaching Geography. New York: Guilford Press.

Gu, X., Song, X., Sun, H., Dong, M., Li, J., Liu, G., Zhang, Z., \& Wu, J. (2016). Teaching Reform of Pharmaceutical Chemistry with PBL Method. Indian Journal of Pharmaceutical Education and Research. Vol 50. Issue 4.

Haengnam, S. (2017). Development of Teaching Methods for Competency Development in Business Class. 디지털산업정보학회 논문지 제13권 제3호-2017년9월. http:// dx.doi.org/10.17662/ksdim.2017.13.3.083

Handoyo, B., \& Purwanto. (2017). Spatial Based Learning and Its Implementation: Learning Innovation. Malang: UM Press.

Hespanha, Stacy R. et.al. (2009). Spatial thinking and technologies in the undergraduate social science classroom. Journal of Geography in Higher Education. 33: 1 S17 S27. http://dx.doi.org/10.1080/03098260903033998

Hooper, K. (1981). The use of computer-controlled video disks in the study of spatial based Learning. Journal of Behavior Research Methods \& Instrumentation 1981 Vol. $13(2), 77-84$.

Hynek, P. (2017). Project-Based Learning in Geography In: Karvánková P, Popjaková D, Vančura M, Mládek J (eds). Current Topics in Czech and Central European Geography Education. Springer Cham Print ISBN 978-3-319-43613-5. Online ISBN 978-3-319-43614-2 https://doi.org/10.1007/978-3-319-43614-2_8

International Union of Biochemistry and Molecular Biology. https://doi.org/10.1002/ bmb.2005.49403306394

Jusuf, A. A. (2009). Spices approach and problem based learning (PBL). Depok: Histology FKUI.

Khoiriyah, A. J., \& Husamah, H. (2018). Problem-based learning: Creative thinking skills, problem-solving skills, and learning outcome of seventh-grade students. JPBI (Jurnal Pendidikan Biologi Indonesia) 4(2), 151-160. https://doi.org/10.22219/ jpbi.v4i2.5804

Kilroy, D. A. (2003). Review Problem-Based Learning. Emergency Medicine Journal 411-413. http://doi:10.1136/emj.2003.012435

Kosasih, E. (2014). Learning strategies and learning implementation of the 2013 Curriculum. Bandung: Yrama Widya.

Kwan \& Chiu-Yin. (2017). Problem-based Learning (PBL) in Medical Education in Taiwan: Observations and a Commentary. Journal of Medicine and Health Vol 6 No. 1.

Lestari, L. R., \& Astuti, L. P. (2017). Increasing student's confidence using group counseling services through a person center approach. Prosiding Seminar 
Jurnal Pendidikan Geografi:

Kajian, Teori, dan Praktik dalam Bidang Pendidikan dan Ilmu Geografi

Volume 25, Nomor 1, Jan 2020, Hal 69-79

Bimbingan dan Konseling Vol 1. No 1. 238-247 ISSN 2579-9908. Retrieved from: http://pasca.um.ac.id/

Lohman, D. F. (1993). Spatial ability and G. paper presented at the first spearman seminar university of Plymouth England. Retrieved from: (http:// faculty.education.uiowa.edu/docs/dlohman/spatial_ability_and_g.pdf?sfvrsn=2)

Masykur, A. M., \& Fathani, A. H. (2007). Mathematical Intelligence. Yogyakarta: Arruzz Media.

Mokhtar, M. Z., Tarmizi, R. A., Ayub, A. F. M., Tarmizi, M. A. A. (2010). Enhancing Calculus Learning Engineering Students Through Problem-Based Learning. Wseas Transactions On Advances In Engineering Education Issue 8 Volume 7 ISSN 1790 $-1979$

Nagel, P. (2008). Geography: The Essential Skill for the 21st Century. Social Education 72(7), pp 354-358. American Public University

Nariman, N., \& Chrispeels, J. (2016). PBL in the Era of Reform Standards: Challenges and Benefits Perceived by Teachers in One Elementary School. Interdisciplinary Journal of Problem-Based Learning. 10(1). htps://doi.org/10.7771/15415015.1521 .

Oberlander, J., \& Talbert-Johnson, C. (2004). Using technology to support problembased learning. Action Teacher Educ 25(4), 48-57.

Osgood, M. P., Mitchell, S. M., \& Anderson, W. L. (2005). Teachers as learners in a cooperative learning biochemistry Class. Biochem. Mol. Biol. Educ. 33(6), 394398.

Overton, T. L., \& Randles, C. A. (2015). Beyond problem-based learning: using dynamic PBL in chemistry. Chemistry Education Research and Practice. 251-259.https:// doi.org/10.1039/c4rp00248b.

Pawson, E, et.al. (2006). Problem-based learning in geography: Towards a critical

Quilis, J. D. S., Antón, A. M., Cabanes, N.C, Martínez, G. M. (2017). Virtualized Computational Environments on the cloud to foster group skills through PBL: A case study in architecture. Computers \& Education. DOI: 10.1016/ j.compedu.2017.02.001

Sakyi, D. A., \& Kuofi, H. A. (2015). Problem-based learning in resource-poor settings: lessons from a medical school in Ghana. BMC Medical Education. DOI 10.1186/s12909-015-0501-4

Scherpbier, A., \& Hillen, H. (2010). Lessons from problem-based learning. Oxford University Press ISBN 0199583447, 9780199583447.

Siler, C. R. (1998). Spatial Dynamics: An Alternative Teaching Tool In The Social Studies. Retreved from: https://eric.ed.gov/?id=ED415179

Sinton, D. S., Kolvoord, B., Gersmehl, P., Bednarz, S., Uttal, D. (2013). The People's Guide to Spatial Thinking. National Council for Geographic Education. Washington DC.

Smith, T., \& Ravitz, J. (2008). Problem based learning in college. Economics Academic Exchange Quarterly 12(1): 22-28

Soares, R., Santos, C., \& Carvalho, S. (2015). PBL, Hands-On/ Digital resources in Geology, (Teaching/Learning). EGU General Assembly. Vienna, Austria. id. 6322.Vol. 17, EGU2015-6322, 2015

Sørensen, M. J. (2017). Teaching consumer law based on PBL principles within a workshop frame. Journal of Problem Based Learning in Higher Education VOL 5 NO 2 Page 39-47http://dx.doi.org/10.5278/ojs.jpblhe.v0i0.1520.

Surya, E., \& Syahputra, E. (2016). Improving High-Level Thinking Skills by 
Jurnal Pendidikan Geografi:

Kajian, Teori, dan Praktik dalam Bidang Pendidikan dan Ilmu Geografi

Volume 25, Nomor 1, Jan 2020, Hal 69-79

Development of Learning PBL Approach on the Learning Mathematics for Senior High School Students. International Education Studies. Vol 10. No 8. ISSN 19139020 E-ISSN 1913-9039 Published by Canadian Center of Science and Education https://doi.org/10.5539/ies.v10n8p12

Szeberenyi, J. (2005). The biological activity of the large-t protein of sv40 virus. Biochem. Mol. Biol. Educ. 33(1), 56-57.

Szulevicz, T., \& Jensen, M. (2013). PBL in Educational Psychology - Potentials and Challenges. Journal of Problem Based Learning in Higher Education. VOL. 1, No. 1, 2013 - Page 19-35. EISSN-2246-0918

Tambunan and Marliah, S. (2006). Relationship between spatial ability and mathematical learning achievement. Depok: Universitas Indonesia.

Velez, M. C, Deborah S., \& Marilyn, T. (2006). Understanding visualization through spatial ability differences. New Jersey: The State University. Retrieved from: http:// citeseerx.ist.psu.edu/viewdoc/download?doi=10.1.1.91.1955\&rep=rep1\&type=pdf

Wijnen, M., Loyens, S. M., Smeets, G., Kroeze, M. J., \& Van der Molen, H. T. (2017). Students' and Teachers' Experiences With the Implementation of Problem-Based Learning at a University Law School. Interdisciplinary Journal of Problem-Based Learning. 11(2) https://doi.org/10.7771/1541-5015.1681

Yew, E. H. J., \& Goh, K. (2016). Problem Based Learning: An Overview of its Process and Impact on Learning. Health Professions Education. http://dx.doi.org/10.1016/ j.hpe.2016.01.004

Yew, E. H. J., \& Schmidt, H. G. (2009). Evidence for Constructive, Self-Regulatory, and Collaborative Processes In Problem-Based Learning. Adv Health Sci Educ 2009. 14 (2): 251-273 Print ISSN: 1382-4996 Online ISSN: 1573-1677 Springer. Netherlands https://doi.org/10.1007/s10459-008-9105-7

Zubairi, M., et al. (2008). Approaching PBL practically: a guide for students by students. Cannada: McMaster University. 